\title{
Nutritional aspects of alcohol consumption
}

\author{
By H. M. Sinclair, Magdalen College, Oxford
}

\section{Is alcohol a nutrient or a food?}

Since alcohol (ethanol) provides calories, it is an aliment, this being defined (Sinclair, I948) as a non-specific chemical compound that is used by the body for the production of energy and may in addition be used for growth or repair. Since a food is something that is ingested and provides one or more aliments or nutrients, alcohol is a food. It is not a nutrient, despite what has been stated in the previous paper (Trémolières, Lowy \& Griffaton, 1972); Trémolières follows the (USA) National Research Council: the Food and Nutrition Board (1964) in considering alcohol to be a nutrient, although the Board does not state a recommended dietary allowance.

\section{Nutritional changes resulting from oxidation of alcohol}

The paths of oxidation of alcohol as just discussed by Trémolières et al. (I972), are through acetaldehyde and acetate to carbon dioxide and water, generating NADH through the main pathway. The increase in the NADH:NAD ratio (Cherrick \& Leevy, 1965 ) results in various metabolic changes that affect nutrition. Some of these may now be discussed.

IIypoglycaemia. This may follow ingestion of alcohol after as much as $3^{\circ} \mathrm{h}$, and may produce unconsciousness that is easily confused with that caused by cerebral depression by alcohol. The hypoglycaemia can occur at any age, for instance in an infant 2 years old (Tolis, 1965), and does not necessarily follow low caloric intakes. Gluconeogenesis is decreased in the liver and in consequence the output of glucose into the blood is diminished (Field, Williams \& Mortimore, 1963; Lochner, Wulff \& Madison, 1967; Krebs, 1968).

Hyperlipaemia and fatty liver. Feigl (1918) described hyperlipaemia in alcoholism. There are two forms in which lipids are carried in plasma, as non-esterified fatty acids combined with albumin (NEFA) and as lipoproteins. The class of the latter that particularly concerns us is that of $S_{f 20^{-}}$(very low density (VLDL), or pre- $\beta$ lipoproteins), which contain relatively large amounts of triglyceride. These are formed in the liver or intestinal mucosa, and give rise to both high density (HDL or $\alpha$ ) and low density (LDL) $\left(S_{f 0}{ }^{-} 20\right.$ or $\left.\beta\right)$ lipoproteins:

$$
\mathrm{HDL} \rightleftharpoons \mathrm{VLDL} \rightarrow \text { intermediate } \rightarrow \text { LDL. }
$$

The changes in NEFA in acute and chronic alcoholism have recently been reviewed by Lieber, Rubin \& DeCarli (197I): a large stressful amount of alcohol (such as $400 \mathrm{~g}$ daily) causes a rise in plasma NEFA probably partly by increased 
liberation from adipose tissue and decreased utilization in the liver; smaller doses cause an immediate fall in NEFA which is accompanied by a rise in plasma acetate, and a similar rise caused by ingesting acetate correspondingly lowers plasma NEFA.

Alcohol increases plasma VLDL (Baraona \& Lieber, 1970) and hence there is a rise in cholesterol, phospholipids and especially in triglycerides. This rise in VLDL is greatly increased if fat is given with the alcohol, but this enhancement is not one due to increased absorption or decreased peripheral utilization.

The production of hepatic triglycerides by combination of dietary fat and alcohol may be sufficiently great to cause marked hyperlipaemia which is associated with haemolytic anaemia, jaundice and fatty liver, a combination known as Zieve's syndrome (Zieve, 1958) though additional factors may play a part (Baraona \& Lieber, rg69).

In rats and non-alcoholic human volunteers alcohol can profoundly affect the ultrastructure and biochemistry of the liver despite adequate aliments, protein and choline. When alcohol (95\%, diluted $\mathrm{I}$ in 6) was isocalorically substituted for carbohydrate in an adequate diet so that it supplied about $44 \%$ of the energy during 12-I $8 \mathrm{~d}$, there was enlargement and marked morphological changes in the mitochondria of the liver, and proliferation of the smooth endoplasmic reticulum (SER). The mitochondria of chronically treated rats oxidized less fatty acids, acetate and chylomicrons, and they respired slower than normal but remained coupled. This excellent work has recently been reviewed by Rubin (1971) and Lieber et al. (197 I).

There are other ultrastructural changes. Mallory (I9II) described hyalin in the liver. By electron-microscopy this is found in the cytoplasm as aggregates of fibrillar material.

Cirrhosis of the liver. This does not necessarily follow fatty liver, which is reversible, and cirrhosis cannot be produced in rats by alcohol alone. There is no doubt that in man the amount of damage caused by alcohol depends upon the amount and period over which it is consumed. For instance, Lelbach $(1967)$ in a study of a large number of alcoholics with a history of ${ }_{1} 5$ years found that only $15 \%$ of those who consumed less than $\mathrm{I} 60 \mathrm{~g}$ daily had severe liver damage whereas this was present in $75 \%$ who consumed more than this amount; after 15 years of addiction, the incidence of severe liver damage was eight times that after 5 years. Conversely, during prohibition or decreased consumption, as in the two World Wars, the death rate from cirrhosis of the liver decreased.

Though some factor in addition to alcohol appears to be needed to produce cirrhosis, there is no evidence as yet that dietary deficiencies are important in this (Steiner, I964; Lelbach, I966; Thaler, 1967). The proliferation in SER and in the microsomal ethanol oxidizing system enzymes and cytochrome $\mathrm{P}-45^{\circ}$ probably accounts for the increased tolerance of alcoholics to barbiturates (Lieber \& Rubin, I968; Rubin \& Lieber, I968). For this proliferation new cellular membranes are required which need proteins, phospholipids such as lecithins containing essential fatty acids (EFA), and free cholesterol. If any of these were in short supply damage to the cell would occur with the possible production of necrosis and fibrosis (cirrhosis). Deficiency of choline, or of methionine which is a methyl donor, can cause cirrhosis 
in the rat, in which animal alcohol apparently increases the choline requirement (Finkelstein \& Kyle, 1968; Lombardi, Pani, Schlunk \& Shi-Hua, 1969). Alcohol decreases protein synthesis in the pancreas of rats in chronic but not acute experiments (Sardesai \& Orten, I 968, I969), and this might be relevant to alcoholic pancreatitis in man; but there seems to be little effect of alcohol on protein synthesis in the liver (Isselbacher \& Greenberger, I964; Seakins \& Robinson, I964). There is an accumulation of cholesterol ester in the liver after giving alcohol (DeCarli \& Lieber, 1967 ), especially on a cholesterol-free diet; this is probably caused by the proliferation of microsomes caused by alcohol, since these synthesize cholesterol.

It appears therefore that only the phospholipid portion of the proliferating cellular membranes might be deficient through shortage of choline, but deficiency of EFA is a further possibility. The results of experiments are very difficult to interpret because of the great rapidity with which EFA are destroyed by oxidation in absence of antioxidants. Thus Zaki, Hoffbauer \& Grande $(1965)$ found that rats on a diet low in protein and deficient in choline developed severest liver damage when given red palm oil and the least when given safflower-seed oil (which contains much more linoleic acid but is very deficient in antioxidants).

Hyperuricaemia. Gout has traditionally been associated with alcohol, and for a century it has been known to be accompanied by hyperuricaemia (Garrod, I854). This condition is common in drunken persons (Lieber \& Davidson, 1962), and infusions of alcohol cause it (Lieber, Jones, Losowsky \& Davidson, 1962) by raising blood lactate which is known to suppress the excretion of uric acid (Yu, Sirota, Berger, Halpern \& Gutman, 1957).

Ketonaemia. Volunteers given alcohol have increased ketones in blood and urine, and there is increased production of ketones in liver slices of rats pretreated with alcohol (Lefevre \& Lieber, 1967 ). Ketones are mainly produced in liver mitochondria.

Increased glutamate. During alcohol intoxication glutamate is increased in brain (Häkkinen \& Kulonen, 1967), which might be important in cerebral depression since the inhibitory compound $\gamma$-aminobutyric acid (GABA) is made by decarboxylation of glutamate in presence of pyridoxal phosphate. Some authors, but not all, have claimed to find increased concentrations of GABA (e.g. Häkkinen \& Kulonen, $\left.19^{6}{ }_{3}\right)$. The matter is still controversial.

\section{Secondary deficiencies caused by alcohol}

Deficiencies of vitamins in alcoholism were reviewed by me previously before this Society (Sinclair, 1955) and since then have been studied extensively by Leevy \& Baker (1968, 1970). The concept of Williams (1950) of 'genetotrophic disease' was discussed earlier (Sinclair, I955); since then no work seems to have supported the idea that nutritional factors may give rise to chronic alcoholism; possible endocrinological factors are reviewed by Jellinek ( 1960 ).

Ingestion and digestion. It is generally accepted that alcohol taken moderately before a meal increases appetite and accelerates digestion of food. Certainly it increases the flow of gastric (Beazell \& Ivy, 1940) and pancreatic secretions (Dreiling, 
Richman \& Fradkin, 1952). However, in chronic alcoholism gastric secretion is frequently impaired and anorexia is common. There may therefore be inadequate ingestion of aliments or nutrients.

Malabsorption. This may be caused by syndromes secondary to disorders of the small intestine, pancreas or liver. Perhaps the most interesting concerns thiamin (Thomson, Baker, Leevy, I968, 1970): the intestinal transport of this vitamin is rate-limited, and by administration of $\left[{ }^{35} \mathrm{~S}\right]$ thiamin these workers showed that oral or parenteral alcohol could reduce its absorption; it was halved in four of twelve alcoholic patients without liver disease. Chronic alcoholism was also found by Tomasulo, Kater \& Iber (1968) to decrease the intestinal absorption of labelled thiamin.

Extra requirements for cell replication. The possibility has been discussed above of deficiencies of choline and essential fatty acids occurring in the liver when alcohol causes increased requirements of these nutrients during proliferation of the SER and destruction of EFA by peroxides if present. Tetrahydrofolate is required for the formation of choline by methyl-transfer from, for instance, methionine.

Mention may be made in this connexion of the work of MacDonald on the relationship of folic acid to iron, and the possible importance of iron in alcoholic cirrhosis of the liver. MacDonald, Jones \& Pechet (1965) found that rats fed on a diet high in iron and low in lipotropic factors deposited excess iron in the liver, and this could be prevented by supplements of folic acid or of choline. It is suggested (MacDonald \& MacSween, 1969) that the excess iron is stored in the reticuloendothelial cells. Certain wines contain large amounts of iron (Aron, Paoletti, Jobard \& Gosse, 1961; MacDonald \& Baumslag, 1964), and their prolonged administration to lower animals causes accumulation of iron (Aron et al. 196r). These two groups of authors also showed that tissues such as the liver accumulated iron in wine-drinkers with cirrhosis. Further, alcohol increases intestinal absorption of iron (Charlton, Jacobs, Seftel \& Bothwell, I964) and iron aggravates cirrhosis produced by other agents (Kent, 1965 ).

Decreased utilization. The liver is important for both storage and metabolism of certain vitamins, and interference with its functions by alcohol can therefore cause secondary nutritional deficiencies. For instance, vitamin $\mathrm{D}_{3}$ (cholecalciferol) is hydroxylated in the liver to the $25-\mathrm{OH}$ compound, which is then further hydroxylated in the kidney to 1,25-dihydroxycholecaliferol (Holick, Schnoes \& DeLuca, I97I). Chronic giving of ethanol reduces the amount of the active form of vitamin $\mathrm{B}_{6}$ (French \& Castagna, 1967 ), which is one of the vitamins most intensively studied in alcoholism. Thiamin is converted into its pyrophosphate, and alcohol inhibits this phosphorylation in the liver (Sinclair, 1955). More than $3 \circ$ years ago I estimated total thiamin in blood, and found this significantly low in all of twenty-five cases of alcoholic polyneuropathy, about half of whom also had Korsakov's psychosis; all of six cases had low values of thiamin pyrophosphate in blood, estimated by an enzymatic method (Goodhart \& Sinclair, 1940). This decreased phosphorylation could be caused by deficient ATP in the liver (Williams \& Bissell, 1944), which deficiency is known to occur in alcoholism (Hyams \& Isselbacher, 1964). Such a failure of 
metabolism of thiamin explains the persistence of peripheral neuropathy and low transketolase activity of erythrocytes in alcoholic cirrhosis despite therapy with thiamin (Fennelly, Frank, Baker \& Leevy, 1967). In delirium tremens, cerebral oxidation mechanisms may be decreased by deficiencies of thiamin pyrophosphate or of magnesium which is needed for the action of thiamin (Tamburro, Kirkland, Cabansag \& Leevy, I968; Zieve, Doizaki \& Stenroos, 1968).

Increased excretion. If the diet is adequate in nutrients and impaired liver function causes decreased storage or utilization, urinary excretion may be increased. Increased excretion could also occur through defects in the kidney. Major studies of storage of vitamins of the $\mathrm{B}$ complex in liver disease have been made (Baker, Frank, Ziffer, Goldfarb, Leevy \& Sobotka, 1964; Leevy, Baker, Tenhove, Frank \& Cherrick, I 965 ).

Ingestion of alcohol increases excretion of magnesium (McCollister, Prasad, Doe \& Flink, I958; Martin \& Bauer, I962; Kalbfleisch, Lindeman, Ginn \& Smith, I963; McCollister, Flink 8 Lewis, I 963 ). The similarity of the symptoms of alcohol withdrawal and magnesium deficiency is noteworthy; the evidence for a connexion has been assessed recently by Wolfe \& Victor (1969).

There are several studies that show increased excretion of zinc in alcoholic cirrhosis, or after alcohol ingestion with low levels of this essential element in liver and plasma (Vallee, Wacker, Bartholomay \& Hoch, 1959; Sullivan, 1962; Prasad, Oberleas \& Halsted, I965).

\section{Advantages of alcohol}

Beer may be good for you. But if so this is largely because a pint will provide approximately the following percentages of the nutritional requirements of a moderately active man: nicotinic acid 66 , riboflavin $\mathrm{r}_{3}$, phosphorus $\mathrm{I} 2$, calcium 8 , calories 7 and thiamin 2. This small contribution may not be all:

Ale, man, ale's the stuff to drink

For fellows whom it hurts to think.

So thought Housman ( 1896 ). This is no place to discuss the social advantages of alcohol which, regretfully, we cannot praise on nutritional grounds. Its merits as a drug are discussed earlier elsewhere (Wilson, I972). Let us recall that it is a vasodilator, a soporific and a diuretic, as was pointed out years ago (Shakespeare, 1623):

PORTER:

'... drink, Sir, is a great provoker of three things.'

MACDUFF:

'What three things does drink especially provoke?'

PORTER:

'Marry, sir, nose-painting, sleep, and urine. Lechery, sir, it provokes, and unprovokes; it provokes the desire, but it takes away the performance.'

In an overpopulated world in which pleasure is so often deficient, perhaps we may welcome this nutritional advantage. 
REFERENCES

Aron, E., Paoletti, C., Jobard, P. \& Gosse, C. (rg6r). Archs Mal. Appar. dig. 50, 745 .

Baker, H., Frank, O., Ziffer, H., Goldfarb, S., Leevy, C. M. \& Sobotka, H. (1964). Am. F. clin. Nutr. I4, I.

Baraona, E. \& Lieber, C. S. (1969). Am. F. clin. Nutr. 22, 356.

Baraona, E. \& Lieber, C. S. (1970). F. clin. Invest. 49, 769.

Beazell, J. M. \& Ivy, A. C. (I940). Q. fl Stud. Alcohol r, 45.

Charlton, R. W., Jacobs, P., Seftel, H. \& Hothwell, T. H. (1964), Br. med. J. ii, 1427.

Cherrick, G. R. \& Leevy, C. M. (1965). Biochim. biophys. Acta 107, 29.

DeCarli, L. M. \& Lieber, C. S. (1967). F. Nutr. gr, 33 I.

Dreiling, D. A., Richman, A. \& Fradkin, N. F. (1952). Gastroenterology 20, 636 .

Feigl, J. (19r8). Biochem. Z. 92, 282.

Fennelly, J., Frank, O., Baker, H. \& Leevy, C. M. (1967). Am. \%. clin. Nutr. 20, 946.

Field, J. B., Williams, H. E. \& Mortimore, G. E. (I963). F. clin. Invest. 42, 497.

Finkelstein, J. D. \& Kyle, W. E. (1968). Proc. Soc. exp. Biol. Med. r29, 497.

French, S. W. \& Castagna, J. (1967). Lab. Invest. 16, 526.

Garrod, A. B. (1854). Trans. med-chir. Soc. Edinh. 37, 49.

Goodhart, R. \& Sinclair, H. M. (1940). F. biol. Chem. 132, 1 1.

Häkkinen, H.-M: \& Kulonen, E. (1963). F. Neurochem. 10, 489 .

Häkkinen, H.-M. \& Kulonen, E. (1967). Biochem, F. 105, 261.

Housman, A. E. (1896). A Shropshire Lad. London: Grant Richards Ltd.

Holick, M. F., Schnoes, H. K. \& DeLuca, H. F. (1971). Proc. natn Acad. Sci. U.S.A. 68, 803.

Hyams, D. E. \& Isselbacher, K. J. (1964). Nature, Lond. 204, $1 \times 96$.

Isselbacher, K. J. \& Greenberger, N. J. (1964). New Engl. F. Med. 270, $35 \mathrm{I}$.

Jellinek, E. M. (1960). The Disease Concept of Alcoholism. New Haven: Hill House Press.

Kalbfleisch, J. M., Lindeman, R. D., Ginn, H. E. \& Smith, W. O. (1963). F. clin. Invest. 47, 447 I.

Kent, G. (1965). In Progress in Liver Diseases Vol. 2, p. 253 [H. Popper and F. Schaffner, editors]. New York: Grune \& Stratton.

Krebs, H. A. (1968). Adv. Enzym. Reg. 6, 467 .

Leevy, C. M. \& Baker, H. (1968). Am. F. clin. Nutr. 21, 1325.

Leevy, C. M. \& Baker, H. (1970). Med. Clins N. Am. 54, 467.

Leevy, C. M., Baker, H., Tenhove, W., Frank, O. \& Cherrick, G. R. (1965). Am.J. clin. Nutr. r6, 339.

Lefevre, A. \& Lieber, C. S. (I967). Clin. Res. 15, 324.

Lelbach, W. K. (1966). Acta hepato-splenol. 13, 321.

Lelbach, W. K. ( 1967). Acta hepato-splenol. 13, 9.

Lieber, C. S. \& Davidson, C. S. (r962). Am. Э. Med. 33, 3 I 9.

Lieber, C. S., Jones, D. P., Losowsky, M. S. \& Davidson, C. S. (I962). 7. clin. Invest. 4I, I863.

Lieber, C. S. \& Rubin, E. (r968). Gastroenterology 54, 642.

Lieber, C. S., Rubin, E. \& DeCarli, L. M. (197x). In The Biology of Alcoholism p. $26_{3}$ [B. Kissin and $H$. Begleiter, editors]. Landon: Plenum Press.

Lochner, A., Wulff, J. \& Madison. L. L. (1967). Metabolism r6, I.

Lombardi, B., Pani, P., Schlunk, F. F. \& Shi-Hua, C. (1969). Lipids 4, 67.

McCollister, R., Prasad, A. S., Doe, R. P. \& Flink, E. B. (1958). F. Lab. clin. Med. 52, 928.

McCollister, R. J., Flink, E. B. \& Lewis, M. D. (I963). Am. Y. clin. Nutr. I2, 415.

MacDonald, R. A. \& Baumslag, N. (1964). Am. F. med. Sci. 247, 649.

MacDonald, R. A., Jones, R. S. \& Pechet, G. S. (I965). Archs Path. 80, 153.

MacDonald, R. A. \& MacSween, R. N. M. (1969). Ann. N.Y. Acad. Sci. 165, I56.

Mallory, F. B. (I 11 1). Bull. Fohns Hopkins Hosp. 22, 69.

Martin, H. E. \& Bauer, F. K. (I 962 ). Proc. R. Soc. Med. 55, grz.

National Research Council: the Food and Nutrition Board (1964). Publs natn. Res. Coun., Wash. no. I 146.

Prasad, A. S., Oberleas, D. \& Halsted, J. A. (1965). F. Lab. clin. Med. 66, 508.

Rubin, E. (I $97 \mathrm{I}$ ). In Metabolic Changes Indaced by Alcohol p. 7o [G. A. Martini and C. Bode, editors.] Berlin: Springer-Verlag.

Rubin, E. \& Licber, C. S. (1 968). Science, N.Y. 162, 690.

Sardesai, V. M. \& Orten, J. M. (1968). F. Nutr. 96, 24 r.

Sardesai, V. M. \& Orten, J. M. (1960). In Biochemical and Clinical Aspects of Alcohol Metabolism p. 155 [V. M. Sardesai, editor]. Springfield Ill.: Charles C. Thomas.

Seakins, A. \& Robinson, D. S. (1964). Biochem. F. 92, 308.

Shakespeare, W. (1623). Macbeth II, iii.

Sinclair, H. M. (1948). Vitams Horm. 6, 101.

Sinclair, H. M. (1955). Proc. Nutr. Soc. 14, 107. 
Steiner, P. E. (1 964). Pathologia Microbiol. 27, 890 .

Sullivan, J. F. (1962). Q. Il Stud. Alcohol 23, 216.

Tamburro, C., Kirkland, M., Cabansag, C. \& Leevy, C. M. (1968). Clin. Res. 16, 353.

Thaler, H. (1967). Germ. med. Mon. 12, 134.

Thomson, A., Baker, H. \& Leevy, C. M. (I968). Am. F. clin. Nutr. 21, 537.

Thomson, A. D., Baker, H. \& Leevy, C. M. (1970). F. Lab. clin. Med. 76, 34 .

Tolis, A. D. (1965). Pediat. Clins N. Am. 12, 423.

Tomasulo, P. A., Kater, R. M. H. \& Iber, F. L. (rg68). Am. J. clin. Nutr, 21, I341.

Trémolières, J., Lowy, R. \& Griffaton, G. (1972). Proc. Nutr. Soc. 31, 107.

Vallee, B. L., Wacker, W. E. C., Bartholomay, A. F. \& Hoch, F. I. (1959). Ann. intern. Med. 50, 1077.

Williams, R. H. \& Bissell, G. W. (1944). Archs intern. Med. 73, 203.

Williams, R. J. (I950). Nutr. Rev. 8, 257.

Wilson, C. W. M. (1972). Proc. Nutr. Soc. 35, 9 I.

Wolfe, S. M. \& Victor, M. (1969). Ann. N.Y. Acad. Sci. 162, 973.

Yu, T. F., Sirota, J. H., Berger, L., Halpern, M. \& Gutman, A. B. (1957). Proc. Soc. exp. Biol. Med. 96, 809 .

Zaki, F. G., Hoffbauer, F. W. \& Grande, F. (1965). Archs Path. 80, 323.

Zieve, L. (1958). Ann. intern. Med. 48, 47 I.

Zieve, L., Doizaki, W. M. \& Stenroos, L. E. (1968). F. Lab. clin. Med. 72, 26 1. 